\title{
KÖNYVISMERTETÉS
}

\author{
Éberhardt Gábor
}

\section{Kihívás és kockázat}

Az államok XXI. századi hazai és nemzetközi kihívásai

a fegyverigazgatás vonatkozásában

\section{Challenge and risk}

Domestic and international challenges for states of the $21^{\text {st }}$ century to weapons management

„Nincs erösebb hadsereg az egész világon, mint egy eszme, amelynek eljött az ideje.'

Victor Hugo

\begin{abstract}
Absztrakt
A 2020-ban megjelent könyv szerzőjének kutatási tárgya Magyarországon és nemzetközi felületen is kevéssé kutatott, speciális rendészeti szakterület. A könyv nagyszámú információt ad az olvasónak a magyar, az európai és más kontinensek országainak lőfegyverrendészetéről. Szintén kevéssé ismert tartalmi eleme a könyvnek a nem halálos és az elektromos fegyverek alkalmazási lehetősége. A könyv írója rengeteg forrás és jogszabály, alkalmazott gyakorlat elemzésével a következtetésekböl kialakított ajánlásokat mutat be.
\end{abstract}

Kulcsszavak: biztonság, kockázat, lőfegyver, rendészet, fegyverigazgatás

\begin{abstract}
The research subject of the author of the book, published in 2020, is a special law enforcement field that is less researched in Hungary and internationally. The book provides the reader with a large amount of information about the fireweapons policing of Hungary, of the countries in Europe and on other
\end{abstract}


continents. Also, a little-known content element of the book is the possibility of using non-lethal and electric weapons. The author of the book presents recommendations gained from the conclusions of analysis a lot of sources and legal rules and applied practices.

Keywords: fireweapon, policing, security, risk, weapons management

A hiánypótló mü ${ }^{1}$ a Nemzeti Közszolgálati Egyetem Közigazgatási Továbbképzési Intézet gondozásában jelent meg 2020-ban (Szabó, 2020). A téma aktualitása nem kérdőjelezhető meg, ha csak a figyelemmel kísért hazai magánbiztonsággal összefüggö kérdésköröket, az egyéni alapjogok változásait vizsgáljuk. A cím alapján ugyanakkor az olvasó azt is elvárja, hogy a szerző globális kitekintéssel mutassa be az aktuális kihívásokat a fegyverek birtoklásának állami szintü szabályozásában, amelyek valós kockázatokat is rejthetnek a társadalom számára.

A kiadó egyetem, a kutatási tevékenység támogatójának emblémáit magán viselő könyv színe épp azzal kelti fel az érdeklődést, hogy nincsenek benne harsány elemek. A visszafogott kék árnyalat, a stílusosan egyszerü karakterek a biztos tudást, a megalapozott információt sugározzák az olvasó felé.

A tartalomjegyzék szerinti 95 oldal első olvasatra egy ilyen egyedi, szakmai és jogi alapokon nyugvó leírás esetén éppen elegendőnek értékelhető úgy, hogy azt bizton végigolvassa, aki először belelapoz. Szerkezeti felépítése a klasszikus kereteknek megfelel, kellően tagolt, a fó és alcímek takarják a mögöttük rejlö információt. Napjainkban a szerzők között nem jelent újdonságot, hogy a köszönetüket tolmácsolják azok felé, akik a munkájukban érdemi segítséget nyújtottak. Az itt sorolt nevek és a szakmai hozzáértésük szintén erősítik azt a feltevést, amely szerint magas színvonalú külső kontroll alkalmazása történt, biztosítva a tudományos színvonalat.

A bevezetés első soraiban a szerző a könyvet fegyverigazgatással foglalkozó szakembereknek ajánlja, ugyanakkor úgy vélem, hogy éppen a téma és annak aktualitása szélesebb körben is érdeklődésre tarthat számot. Victor Hugo hivatkozott gondolata irányt mutat a könyv tartalmára, a témának a szerző által felmutatott elméleti és érzelmi vetületeire.

1 A „Google Tudós” a fegyverrendészet címre kilenc találatot adott, amelyből hat esetében Szabó Csaba a szerző, csakúgy a fegyverigazgatás szó esetében adott hat publikációnál is. A nemzetközi kitekintés érdekében vizsgált „,Taylor \& Francis” a , weapon policing” címkutatásra hat, a „weapon administration” címre hét publikált tanulmányt mutatott. Azonos keresésekre a Springer 28, illetve 6 közétett publikációt kezel. 
A kutatásmódszertant megismerve azt láthatjuk, hogy a forráskutatás nemzeti és nemzetközi felületen is széleskörü, amelyhez a kapcsolódó hazai és külföldi, az Amerikai Egyesült Államokból származó többségi normatív szabályzó bemutatása, összehasonlító elemzése történt meg.

Az első rész olyan tüzfegyverekhez kötődő biztonságpolitikai kihívásokat vizsgált, amelyek a negyedik ipari forradalom (Bojár, 2018) termékeinek értékelhetők. A globális és innovatív technológiafejlesztés a tüzfegyvereket sem hagyta a hagyományos szinten. A szerző az egyik - talán a legkritikusabbnak értékelhető - kiemelt biztonsági kockázatokat rejtő 3D nyomtatási technológiát, annak történeti és müszaki fejlődését ismerteti. A müszaki precizitáson túl a technológia elérhetősége és felhasználhatósága, a rendszeresített rendészeti kutatóeszközök által nehézségekbe ütköző azonosítási lehetősége az ilyen készítésủ eszközöket a bünelkövetők, terroristák kedvelt fegyverévé tette. A biztonsági kockázatokat a szintén ilyen módszerrel készített löszerek, a speciális vegyületekből alkotott, löport helyettesítő anyagok a biztonsági kihívásokat a felelős szervek, magánbiztonsági szolgáltatók irányában tovább emeli. A kialakult és dinamikusan növekvő biztonsági kockázatok csökkentésére ajánlásként fogalmazódik meg, a szakmai alapokon nyugvó kockázatelemzésen túl, a 3D technológia hozzáférhetőségét állami monopólium alá helyezése. Tanulmányozhatjuk az Európai Bizottság négy elemből álló stratégiai tervét, a kriminalizációs törekvéseit, amelyek kapcsolódó büncselekményi tényállásokat írnak le, illetve az ilyen eszközök készítésének, alkalmazásának teljeskörü betiltását javasolja. A nemzeti jog az ajánlások egy részét átvette, más elemeit egyéb, súlyozott módon kezeli. Magyarország esetében szintén megállapítható, hogy valós és kiemelt kockázati tényezőként kezeli a 3D nyomtatással előállítható tüzfegyvereket. Továbbgondolásra és a hatáskörrel bíró szervezetek felé megalapozott ajánlásokkal zárul a fejezet, amely a probléma felvetésére, a legjobb gyakorlatok bemutatására épülő, a változó környezeti hatásoknak és társadalmi igényeknek megfelelő normatív korrekciókat ismertet. A kötet második része a lőfegyvertartási jog szabályozási környezetét vizsgálja, elemzi, s nemzetközi összevetéseket végez. A szerző már az első mondatában felhívja arra a figyelmet, hogy (Magyarországon) a lőfegyver tartása nem tartozik az alapjogok közé. Ezzel a környezettel szemben mutatja be az Amerikai Egyesült Államok egyes szövetségi tagállamaiban a liberális, a tüzfegyverek önvédelmi alapjogként biztosított szabályozását. Kevéssé ismert például a spanyol gyakorlat, amely a magánbiztonsági szektorban biztosítja, ugyanakkor szigorú keretek között is tartja a löfegyverek birtoklásának lehetöségét. Adott társadalom tagjaként, a bennünket körülvevő lokális, kontinensnyi és globális változások, biztonsági kihívások kezelésére, szükségszerüen vizsgálni kell a lőfegyvertartás szabályainak korrekciós környezetét. Szabó Csaba a kutatási 
eredményei alapján azt az irányvonalat erősíti, amely szerint a magánszemélyek esetében továbbra is minimális szinten indokolt tartani a lőfegyverek tartásának lehetőségét, azt is célhoz kötötten, állami hatóság engedélye, felügyelet alatt. Felhívja arra is a figyelmet, hogy a biztonsági változások, igények miatt a magánbiztonsági szektor esetében ezt a jogosultságot célszerü biztosítani a jogalkotónak. Ezeket a gondolatait a tudományos felvetései között ismerteti, hivatkozva és ajánlva megoldási és nemzetközi gyakorlatok absztrahálásával történő szabályozást, képzést, ellenőrzést, hatósági tevékenységet, a kooperatív biztonsági modellre (Rosenau, 1990) alapozva. A változó környezet követése közben súlyozott elemként jelöli meg egy új, a magánbiztonsági szektor lőfegyver tartására, kezelésére vonatkozó törvényi szabályozás igényét, valamint a társadalom egészét védelmező rendészeti hatóság megkerülhetetlen pozicionáltságát.

A könyv harmadik része az új társadalmi és politikai érdekek összefüggéseit vizsgálja, több nemzetállami szabályozást bemutatva, elemezve. Úgy vélem, hogy Baum, Depauwés Duquet 2014. évi megközelítése a Föld bármely országában helytálló gondolat, amely szerint „a löfegyver-szabályozás jelentős mértékben átpolitizált fogalom, amely politikailag érzékeny terület" (Baum, Depauw, \& Duquet, 2014). Az egyén biztonsági igénye, hiátusa az őt, környezetét ért agresszióra válaszként megjeleníti a lőfegyverrel történő önvédelmet is. Ezek az egyéni, a társadalmak csoportjait, egészét érintő igények a média, a társadalmi szereplők közvetítésének útján képesek egyre nagyobb teret nyerni, jogalkotói szintig eljutni. A jogalkotás és a nemzeti politika párhuzama kevéssé vitatott, a jogalkotót is megtestesítő politikai szereplők az ideológiájuk, a képviselt közösségük elvárásai függvényében formálódnak. Érdemi kontrollt a jog hatalma, az azt megtestesítő legmagasabb szintü nemzeti vagy nemzetközi bírósági fórumok képesek gyakorolni. Szabó Csaba ebben a fejezetrészben bemutatja a jogalkotást is befolyásolni képes amerikai fegyvergyártó lobbi tevékenységét, a paradoxonelmélet értelmezését. A magánszemélyek fegyvertartásának alapjogát képviselő elvekkel szembe állítva mutatja be az Európai Bizottság vonatkozó irányelvét, annak felülvizsgálati igényét a kontinensen elkövetett terrorcselekmények megközelítéséböl.

A negyedik részben leírtak e sorok írójának igazi szakmai kuriózum, amit szintén nemcsak a szakhatóság, a területen dolgozni tervezők, hanem az átlag olvasók részére is ajánlok. A nem halálos fegyver elnevezés már önmagában is felkeltheti az érdeklődést. A gondolatkör felvezetése során a szerző is leírja, hogy adott eszközöket lehet ugyan azonosító pontok alapján besorolni, de nincs egységesen elfogadott fogalmi, jogi definíció az elnevezésre vonatkozóan. Alapkérdésként merül fel az íróban és az olvasóban is, hogy ha már fegyver, akkor az miért nem a biztonságot veszélyeztető lény megsemmisítését biztosítja? Ezzel a gondolattal 
áll mereven szemben az élet védelmének primátusa, annak megóvásának az igénye. Ezek az elméleti felvetések már rá is mutatnak a szerző kutatási eredményein alapuló válaszaira, amely a katonai és a biztonsági, a rendészeti célok alapján különíti el a fegyvertípusok alkalmazhatósági kereteit. Megismerhetjük az európai államok által alkalmazott eltérő jogi megközelítéseket és szabályozókat, valamint egyes rendészeti szervek által rendszeresített eszközöket. Önálló cím alatt olvashatunk a vezetett elektromos fegyverek alkalmazásának etikai és jogi aspektusairól. A társadalom tagjai eltérően kezelik ezt a kérdéskört is, hivatkozva az egészségügyi kockázatokra, az alkalmazó visszaélési lehetőségeire. A szerző leírja azokat az ismertté vált elemeket is, amelyek megkérdőjelezik az ilyenfajta eszközök biztonságos, célzott, hatékony alkalmazhatóságát.

Szabó Csaba az egyes főbb tartalmi részek összegzését végrehajtja, kutatási eredményeit leírja. Jogos kérdésként merül fel viszont az olvasóban, hogy milyen gondolatokkal tudja lezárni ezt az igen érdekes szakterületi kutatási anyagot? A választ az alcím adja meg, amely a hatósági feladatrendszer tevékenységét vizsgálja. Felmerül a szerzőben az a kérdés, hogy a kapcsolódó feladatok a rendészet, avagy az igazgatás fogalmi köre által fedett? Miután a könyv címében erre egyértelmüen a fegyverigazgatásra teszi le voksát, így a két megközelítés leirata mellett az olvasóra is bízza ennek a kérdéskörnek a további megvitatását, annak megválaszolását.

\section{Felhasznált irodalom}

Baum, T., Depauw, S. \& Duquet, N. (2014). Belgische wapenhandel. Belgian Arms Trade. Leuven \& Den Haag, 25.

Bojár G. (2018). Negyedik ipari vagy harmadik informatikai forradalom? Az információ sok ezer éves hatalma. Magyar Tudomány, 179(1), 37-46. https://doi.org/10.1556/2065.179.2018.1.4

Rosenau, J. N. (1990). Turbulence in World Politics. A Theory of Change and Continuity. Princeton University Press. https://doi.org/10.1515/9780691188522

Szabó Cs. (2020). Kihivás és kockázat - Az államok XXI. századi hazai és nemzetközi kihívásai a fegyverigazgatás vonatkozásában. Nemzeti Közszolgálati Egyetem, Közigazgatási Továbbképzési Intézet

\section{A cikk APA szabály szerinti hivatkozása}

Éberhardt G. (2021). Kihívás és kockázat. Az államok XXI. századi hazai és nemzetközi kihívásai a fegyverigazgatás vonatkozásában. Belügyi Szemle, 69(4), 693-697. https://doi.org/10.38146/ BSZ.2021.4.12 